\title{
Pengaruh Lokasi, Harga dan Fasilitas terhadap Keputusan Sewa Kamar Kost Mahasiswa Fakultas Ekonomi Universitas Samudra
}

\author{
Suri Amilia ${ }^{\left.1^{*}\right)}$, Iriyani $^{2)}$ \\ ${ }^{1 *, 2)}$ Program Studi Manajemen, Fakultas Ekonomi, Universitas Samudra \\ e-mail: suri.amilia@ unsam.ac.id ${ }^{1 *)}$
}

\begin{abstract}
Abstrak
Tujuan dari penelitian ini adalah untuk mengetahui lokasi, harga dan fasilitas keputusan sewa kamar kost mahasiswa Fakultas Ekonomi Universitas Samudra. Metode analisis data menggunakan regresi linier berganda, dengan persamaan analisis regresi linier berganda dalam penelitian adalah: $Y=2,597$ $+0,184 X 1+0,184 X 2+0,044 X 3$. Nilai Adjusted $R$ Square yang diperoleh sebesar 0,17 atau 17,0\% menunjukkan kemampuan lokasi, harga dan fasilitas keputusan sewa kamar kost mahasiswa Fakultas Ekonomi Universitas Samudra, sedangkan sisanya 83,0\% dipengaruhi oleh variabel lain yaitu tidak sesuai dengan penelitian ini seperti keamanan dan kelompok acuan, dan lan-lain. Dari hasil uji coba pada lokasi yang signifikan terhadap keputusan sewa kamar kost dan hipotesis yang diterima, harga tidak signifikan terhadap keputusan sewa kamar kost dan hipotesis ditolak, dan fasilitas tidak signifikan terhadap keputusan kamar sewa dan hipotesis ditolak. Dari hasil uji simultan membuktikan lokasi, harga dan fasilitas simultan berpengaruh signifikan terhadap keputusan sewa kamar mahasiswa Fakultas Ekonomi Universitas Samudra dan hipotesis diterima.
\end{abstract}

Kata kunci: Fasilitas; Harga; Lokasi; dan Keputusan Sewa Kamar

\begin{abstract}
The objective of the research was to find out the location, price and facilities of rental room decisions of the students Fakultas Ekonomi Universitas Samudra. Data analysis method using multiple linear regression, with multiple linear regression analysis equation in research are: $Y=2.597+0.184 X 1+0.184 X 2+$ $0.044 X 3$. The value of Adjusted $R$ Square obtained by 0,17 or 17,0\% indicates the ability of the location, price and facilities of rental room decisions of the students Fakultas Ekonomi Universitas Samudra, while the remaining $83.0 \%$ is influenced by other variables that are not in accordance with this study such as research, security and other relationships etc. From the results of trials on the location of the lease significant to the rental room decision and the hypothesis accepted, the price does not matter significantly to the rental room decision and the hypothesis rejected, and the facilities are not significant to the rental room decision and the hypothesis rejected. From the trial results prove the location, price and simultaneous facilities significantly influence room rental decisions the students Fakultas Ekonomi Universitas Samudra and the hypothesis accepted.
\end{abstract}

Keywords: Facilitie; Location; Price; and Rental Room Decisions 


\section{PENDAHULUAN}

Pendidikan merupakan fondasi dasar suatu bangsa untuk menjadi bangsa yang besar. Pendidikan diperlukan untuk dapat menghadapi persaingan yang semakin ketat dan menyaring pengaruh budaya asing sehingga budaya yang masuk dapat disesuaikan dengan budaya bangsa Indonesia. Pemerintah mulai melakukan perbaikan kualitas pendidikan, tidak hanya di ibukota tetapi kini di kota-kota besar di Indonesia sudah banyak terdapat Perguruan Tinggi baik Negeri maupun Swasta. Salah satu kota yang sudah dikenal dengan kota pendidikan adalah Kota Langsa. Setiap tahunnya ribuan calon mahasiswa baru datang ke Kota Langsa. Kota Langsa menawarkan berbagai bidang ilmu pendidikan yang dapat dipilih oleh calon mahasiswa yang akan meneruskan pendidikannya ke jenjang yang lebih tinggi, dan diharapkan calon mahasiswa dapat memilih bidang sesuai dengan minat dan bakat yang dimilikinya agar mendapatkan hasil yang maksimal dan terbaik. Maka dari itu Kota Langsa layak dijadikan sebagai referensi bagi calon mahasiswa untuk memilih dan melanjutkan pendidikan.

Salah satu perguruan tinggi yang ada di Kota Langsa adalah Universitas Samudra yang berlokasi di Jalan Meurandeh, Kecamatan Langsa Lama, Kota Langsa, Aceh. Ada lima fakultas yang terdapat di Universitas Samudra, salah satunya adalah Fakultas Ekonomi yang terletak di Gampong Meurandeh Tengah. Sebagian besar mahasiswa Fakultas Ekonomi berasal dari luar daerah yang mengharuskan mereka memiliki tempat tinggal di Kota Langsa. Namun, keterbatasan sarana yang disediakan oleh pemerintah Kota Langsa menjadikan mahasiswa yang berasal dari luar daerah kesulitan dalam hal tempat tinggal. Maka dari itu diperlukannya sebuah tempat tinggal sementara atau sering disebut dengan rumah kost. Rumah kost adalah sejenis kamar sewa yang disewa (booking) selama kurun waktu tertentu (wikipedia), biasanya sewa kamar dilakukan selama kurun waktu satu tahun. Banyak faktor yang mempengaruhi mahasiswa dalam pemilihan rumah kost, diantaranya adalah faktor lokasi, harga, dan fasilitas.

Lokasi yang strategis dapat mempermudah dan memperlancar seseorang dalam melakukan segala aktivitas. Faktor lokasi berpengaruh terhadap keputusan mahasiswa dalam memilih tempat kost. Lokasi yang mudah dijangkau dan dekat dengan kampus merupakan lokasi yang tepat untuk mahasiswa memilih tempat kost. Sebelum seseorang atau sekelompok orang memutuskan untuk melakukan pembelian, mereka juga akan mempertimbangkan lokasi yang akan mereka pilih. Faktor harga juga sangat penting untuk dipertimbangkan. Harga merupakan salah satu unsur yang mempengaruhi kegiatan-kegiatan dalam perusahaan yang berfungsi menciptakan keunggulan kompetitif bagi perusahaan. Harga juga merupakan sejumlah uang yang harus dibayar oleh konsumen untuk mendapatkan suatu barang atau jasa yang diinginkan.

Selain itu, faktor fasilitas juga sangat penting untuk diperhatikan. Segala sesuatu yang dapat memperlancar sebuah kegiatan atau aktivitas dapat disebut sebagai fasilitas. Ketersediaan fasilitas yang memadai dan sesuai dengan harga yang ditetapkan akan mempermudah setiap mahasiswa dalam 
memilih tempat kost. Dengan adanya fasilitas yang disediakan, maka mahasiswa tidak perlu lagi membeli barang yang dibutuhkan untuk keperluan di tempat kost.

Dalam penelitian ini yang menjadi objek penelitian adalah mahasiswa Fakultas Ekonomi Universitas Samudra yang memilih tinggal ditempat kost. Berdasarkan hasil wawancara yang dilakukan terhadap 30 orang mahasiswa Fakultas Ekonomi Universitas Samudra ditemukan beberapa fenomena dari setiap variabel-variabel penelitian yang diangkat. Dalam lokasi peneliti menilai bahwa masih kurangnya tempat kost yang terdapat di sekitar Fakultas Ekonomi sehingga masih banyak mahasiswa Fakultas Ekonomi yang bertempat tinggal jauh dari kampus Fakultas Ekonomi, sehingga mahasiswa memerlukan kendaraan pribadi atau transportasi umum seperti becak untuk dapat sampai ke kampus.

Pada harga ditemukan fenomena bahwa harga yang diberikan atau ditetapkan tidak sesuai dengan kriteria tempat kost yang baik, karena seringnya harga sewa kamar kost yang mahal dan ukuran kamar yang kecil namun pemilik kost menetapkan jumlah orang yang menempati satu kamar kost melebihi kapasitas yang seharusnya. Pada fasilitas terdapat fenomena bahwa masih banyak tempat kost yang belum menyediakan fasilitas yang memadai. Penetapan harga yang mahal namun fasilitas yang tidak lengkap juga menjadi sebuah pengaruh dalam mahasiswa memilih tempat kost. Mahasiswa sering mengeluh mengenai fasilitas yang menghambat mereka melakukan segala aktivitas, seperti susahnya air, biaya listrik dan uang kost yang terpisah sehingga mahasiswa harus mengeluarkan biaya tambahan lagi untuk membayar listrik, tempat parkir yang tidak memadai dan tidak adanya fasilitas yang tersedia didalam kamar kost seperti kasur dan lemari.

Tujuan dalam penelitian ini adalah: (1) Untuk mengetahui pengaruh lokasi terhadap keputusan sewa kamar kost pada Mahasiswa Fakultas Ekonomi Universitas Samudra. (2) Untuk mengetahui pengaruh harga terhadap keputusan sewa kamar kost pada Mahasiswa Fakultas Ekonomi Universitas Samudra. (3) Untuk mengetahui pengaruh fasilitas terhadap keputusan sewa kamar kost pada Mahasiswa Fakultas Ekonomi Universitas Samudra. (4) Untuk mengetahui pengaruh lokasi, harga, dan fasilitas secara simultan terhadap keputusan sewa kamar kost pada Mahasiswa Fakultas Ekonomi Universitas Samudra.

\section{TINJAUAN PUSTAKA}

\section{Pengertian Lokasi}

Lokasi merupakan salah satu unsur dalam bauran pemasaran yang memegang peranan penting dalam hal mengalokasikan barang atau jasa dan melancarkan arus barang atau jasa dari produsen ke konsumen. Heizer \& Render (2015) mengatakan lokasi adalah pendorong biaya dan pendapatan, maka lokasi seringkali memiliki kekuasaan untuk membuat strategi bisnis perusahaan. Lokasi yang strategis bertujuan untuk memaksimalkan keuntungan dari lokasi bagi perusahaan. 


\section{Indikator Lokasi}

Indikator-indikator variabel lokasi dalam penelitian mengacu pada penelitian yang dilakukan oleh Resmi dan Mekarsari (2011), yang meliputi:

1. Dekat kampus

Jika memilih lokasi yang dekat dengan kampus, itu tentu akan menghemat waktu, tenaga dan juga biaya untuk perjalanan ke kampus. Hal ini sangat membantu bagi mahasiswa yang tidak memiliki kendaraan. Selain itu, lokasi yang dekat dengan kampus juga akan mempermudah mahasiswa beradaptasi dengan lingkungan.

2. Dekat jalan raya

Memilih lokasi dekat jalan raya juga sangat mempermudah mahasiswa dalam akses transportasi.

3. Dekat teman sedaerah

Jika berada satu kost dengan teman sedaerah, mempermudah dalam hal sosialisasi dan komunikasi dengan teman-teman.

4. Dekat rumah makan

Ini juga bagian penting dalam memilih lokasi kost, karena dekatnya dengan banyak rumah makan akan mempermudah mahasiswa untuk memilih suatu makanan sehingga menunya tidak menjemukan. Tempat makan yang bisa pesan-antar juga sangat membantu ketika sedang hujan, jadi tidak perlu hujan-hujanan untuk makan tinggal pesan saja.

\section{Pengertian Harga}

Pengertian harga menurut Kotler, adalah sejumlah uang yang dibebankan pada suatu produk tertentu. Perusahaan menetapkan harga dalam berbagai cara. Di dalam perusahaan kecil, harga sering kali ditetapkan oleh manajemen puncak. Di perusahaan-perusahaan besar, penetapan harga biasanya ditangani oleh para manajer divisi atau manajer lini produk. Bahkan dalam perusahaan-perusahaan ini, manajemen puncak menyusun tujuan dan kebijakan tentang penetapan harga umum dan sering kali menyetujui harga yang diusulkan oleh manajemen peringkat bawah.

\section{Indikator Harga}

Menurut Hajar, Susilawati, dan Nilakusmawati (2012), indikator-indikator harga yaitu sebagai berikut:

1. Persaingan harga

Dalam menjalankan bisnis rumah kost persaingan harga merupakan salah satu faktor penentu calon penyewa untuk menyewa rumah kost. Calon penyewa kost akan melakukan perbandingan antara satu tempat kost dengan yang lainnya. Pemilik kost harus memiliki cara bagaimana usaha rumah kost yang didirikan akan terus diminati oleh para pencari rumah kost. 
2. Sewa bulanan

Harga sewa kost merupakan salah satu faktor kunci yang menentukan keberhasilan sebuah bisnis kost. Karena harga sewa sangat menentukan keputusan calon penyewa dalam menyewa sebuah kost. Harga sewa yang terlalu tinggi tentu akan membuat kost tidak diminati oleh penyewa, demikian pula bila harga sewa kost terlalu rendah, maka keuntungan yang didapatkan oleh pengusaha kost menjadi sedikit, bahkan pengusaha kost berisiko mengalami kerugian. Maka dari itu pemilik kost bisa menetapkan harga sewa kamar kost yang dapat dibayar perbulan, hal ini juga mempermudah mahasiswa agar dapat menyisihkan uang sakunya setiap bulan karena tidak semua mahasiswa berasal dari keluarga yang berkecukupan.

3. Sewa tahunan

Sewa kost pertahun dapat lebih menghemat biaya kost dibandingkan sewa bulanan, walaupun terasa berat di awal pembayaran tetapi jika harga sewa kost perbulan dihitung satu tahun maka akan semakin mahal dari harga sewa kost pertahunnya.

4. Adanya diskon harga

Diskon harga juga sangat penting yang harus diberikan pemilik kost kepada penyewa kost. Pemilik kost juga bisa memberikan diskon harga jika penyewa kost membayar uang sewa kost secara tunai (cash) di awal. Dengan adanya diskon harga maka penyewa kost bisa mempertimbangkan keputusan untuk memilih kost tersebut. Misal, jika harga sewa kost Rp 300.000/bulan, dan Rp 3.600.000/tahun, maka pemilik kost dapat memberikan diskon harga sebesar Rp 100.000 jika mahasiswa ingin menyewa selama satu tahun. Jadi mahasiswa dapat membayar Rp 3.500.000/tahun.

\section{Pengertian Fasilitas}

Menurut Daradjat, seorang pakar psikologi Islam, fasilitas adalah segala sesuatu yang bisa mempermudah upaya serta memperlancar kerja dalam rangka mencapai suatu tujuan tertentu. Sedangkan Arikunto yang merupakan dosen dan peneliti di bidang pendidikan dan penelitian, fasilitas merupakan segala sesuatu hal yang dapat memudahkan dan memperlancar pelaksanaan segala sesuatu usaha.

\section{Indikator Fasilitas}

Menurut Hajar, Susilawati, dan Nilakusmawati (2012), indikator-indikator fasilitas yaitu sebagai berikut :

1. Fasilitas umum

Adanya fasilitas umum seperti tempat parkir yang aman sangat diperlukan bagi mahasiswa yang memiliki kendaraan pribadi, mahasiswa akan memilih tempat kost yang memiliki tingkat keamanan yang tinggi. Fasilitas umum lainnya adalah tempat berkunjung jika ada tamu yang 
datang. Jadi jika ada keluarga yang berkunjung, maka tidak harus masuk ke dalam kamar kost karena sudah adanya tempat berkunjung yang telah disediakan oleh pemilik kost.

2. Fasilitas kamar kost

Para penyewa kost juga mencari fasilitas kamar kost yang lengkap, seperti tersedia nya lemari, meja belajar dan tempat tidur didalam kamar, selain itu mahasiswa juga membutuhkan toilet/WC disetiap kamar kost. Hal ini dikarenakan terkadang mahasiswa malas harus mengantri terlalu lama jika ingin ke toilet. Maka dari itu pemilik kost harus menyediakan berbagai fasilitas yang dapat mempermudah penyewa kost saat memilih tempat kost tersebut.

3. Fasilitas tambahan

Fasilitas tambahan yang dapat disediakan oleh pemilik kost adalah tersedianya Wi-Fi di sekitar rumah kost. Mahasiswa akan mencari tempat kost yang bisa selalu terhubung ke jaringan internet. Hal ini mempermudah mahasiswa dalam mengerjakan setiap tugas yang diberikan, adanya Wi-Fi disekitar rumah kost juga dapat menghemat pengeluaran mahasiswa dalam membeli paket internet. Dengan adanya fasilitas tambahan seperti ini maka mahasiswa akan memilih kost tersebut sebagai tempat tinggal. Fasilitas seperti kipas angin, AC dan televisi juga bisa menjadi fasilitas tambahan yang dapat disediakan oleh pemilik kost. Namun, jika kamar kost dilengkapi dengan fasilitas tambahan maka penyewa kost juga harus membayar lebih tinggi dari kamar kost yang tidak memiliki fasilitas tambahan.

\section{Pengertian Keputusan Mahasiswa Memilih Tempat Kost}

Keputusan mahasiswa memilih tempat kost adalah suatu tindakan yang dilakukan mahasiswa dalam memilih tempat kost untuk pemenuhan kebutuhan dan diakhiri dengan melakukan seleksi atas alternatif-alternatif tentang tempat kost yang tersedia.

\section{Indikator Keputusan Pembelian}

Adapun indikator keputusan pembelian menurut Fifyanita dan Kamal (2012) yaitu sebagai berikut:

1. Kesesuaian dengan kemampuan finansial

Calon penyewa kost akan memilih kost sesuai dengan kemampuan finansial nya. Sesuainya harga kost dengan fasilitas yang diberikan juga mempengaruhi penyewa kost dalam mengambil keputusan untuk memilih tempat kost tersebut. Semakin mampu seseorang dalam memenuhi kebutuhannya maka semakin besar keinginannya untuk memilih tempat kost yang terbaik.

2. Mudah dijangkau atau tidaknya lokasi rumah kost yang akan dipilih

Rumah kost yang mudah dijangkau akan diminati banyak mahasiswa, keterjangkauan lokasi rumah kost dengan berbagai sarana dan fasilitas akan mempermudah mahasiswa dalam berbagai kegiatan yang dilakukan. Maka mahasiswa akan memilih tempat kost yang dekat dengan kampus dan fasilitas umum lainnya. 
3. Kesesuaian rumah kost dengan keinginan

Mahasiswa akan memilih tempat kost sesuai dengan keinginannya yang dapat bermanfaat bagi mahasiswa tersebut. Namun jika mahasiswa menginginkan rumah kost yang baik maka mahasiswa juga harus bisa membayar uang sewa kost sesuai dengan fasilitas yang diinginkan.

4. Kenyamanan rumah kost sebagai tempat tinggal

Mahasiswa akan mencari rumah kost yang nyaman dan aman untuk ditempati. Karena mahasiswa akan menjadikan rumah kost sebagai tempat tinggal sementara saat jauh dari orangtua. Terlebih jika mahasiswa yang memilih tinggal ditempat kost adalah wanita, maka perlu pertimbangan yang besar dalam memilih rumah kost. Karena jika tidak adanya kenyamanan maka mahasiswa akan sering berpindah-pindah kost.

\section{Faktor-Faktor yang Mempengaruhi Keputusan Sewa Kamar Kost}

Menurut Resmi dan Mekarsari (2011), faktor-faktor yang mempengaruhi keputusan sewa kamar kost yaitu sebagai berikut:

1. Faktor Lokasi

Lokasi merupakan faktor utama mahasiswa dalam memutuskan untuk menyewa sebuah kamar kost yang diukur dari letak rumah kost yang strategis, dan mudah dijangkau.

2. Faktor Harga

Harga juga merupakan sebuah pertimbangan awal sebelum mahasiswa memutuskan untuk menyewa kamar kost berdasarkan tingkat pendapatan orangtua yang diukur dari harga yang ditawarkan terjangkau, dapat bersaing, sewa bulanan, sewa tahunan, diskon, dan adanya toleransi dalam pembayaran.

3. Faktor Fasilitas

Fasilitas adalah faktor-faktor yang tersedia baik didalam maupun diluar rumah kost. Di dalam kamar kost seperti lemari, tempat tidur, dan kamar mandi. Di luar kamar seperti tempat parkir, dan ruang tamu.

4. Faktor Lingkungan

Lingkungan adalah faktor-faktor yang ada baik di dalam maupun di luar rumah kost yang diukur dari kenyamanan (tempat istirahat), sarana fotocopy, rumah makan, dan internet.

5. Faktor Keamanan

Keamanan juga merupakan faktor yang penting bagi mahasiswa dalam memilih rumah kost. Mahasiswa akan memilih rumah kost yang aman dari pencurian dan dekat dengan pemilik rumah ataupun rumah warga. 


\section{Kerangka Pemikiran}

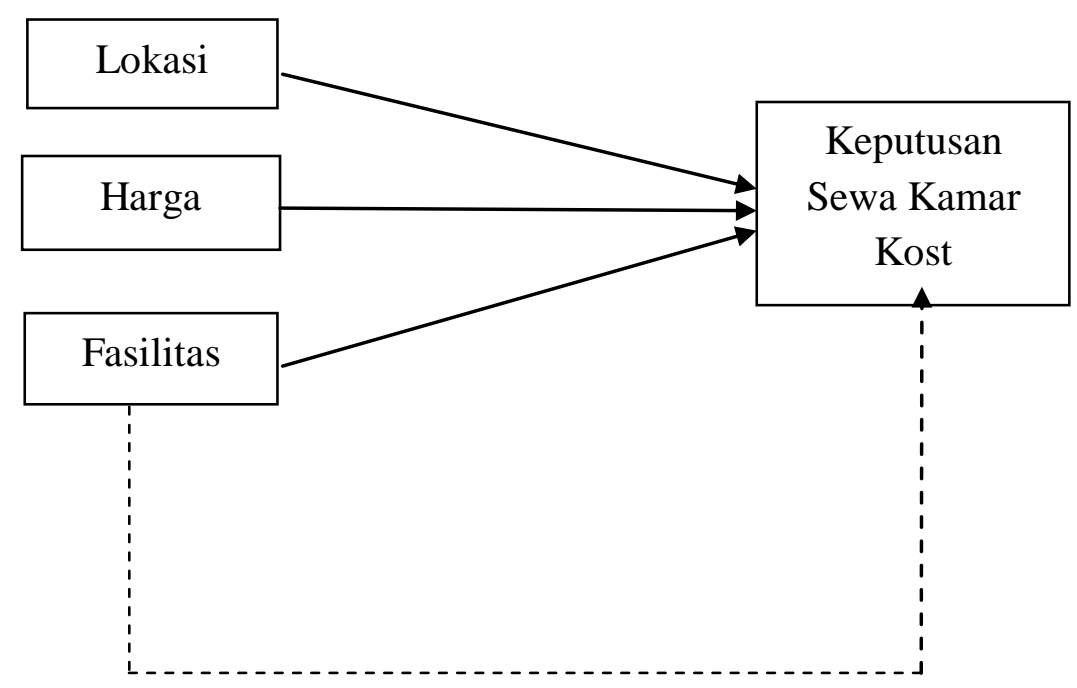

\section{Gambar 1. Kerangka Konseptual}

Keterangan:

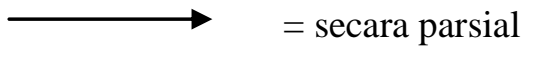

$\ldots-\ldots \quad=$ secara simultan

\section{Hipotesis}

Hipotesis dalam penelitian ini adalah:

1. Lokasi berpengaruh signifikan terhadap keputusan sewa kamar kost pada Mahasiswa Fakultas Ekonomi Universitas Samudra.

2. Harga berpengaruh signifikan terhadap keputusan sewa kamar kost pada Mahasiswa Fakultas Ekonomi Universitas Samudra.

3. Fasilitas berpengaruh signifikan terhadap keputusan sewa kamar kost pada Mahasiswa Fakultas Ekonomi Universitas Samudra.

4. Lokasi, harga, dan fasilitas secara simultan berpengaruh signifikan terhadap keputusan sewa kamar kost pada Mahasiswa Fakultas Ekonomi Universitas Samudra.

\section{METODE PENELITIAN}

\section{Objek dan Waktu Penelitian}

Penelitian dilakukan pada mahasiswa Fakultas Ekonomi Universitas Samudra yang berlokasi di Desa Meurandeh Kecamatan Langsa Lama Kota Langsa, Aceh, Indonesia. Waktu penelitian dilakukan dari bulan November 2018 sampai dengan Mei 2019.

\section{Populasi dan Sampel}

Menurut Sugiyono (2014) menyatakan bahwa populasi adalah wilayah generalisasi yang terdiri atas objek/subyek yang mempunyai kuantitas dan karakteristik tertentu yang ditetapkan oleh 
peneliti untuk dipelajari dan kemudian ditarik kesimpulannya. Populasi dalam penelitian ini mahasiswa aktif yang memilih tinggal ditempat kost. Menurut Sugiyono (2014), sampel merupakan bagian dari jumlah dan karakteristik yang dimiliki oleh populasi tersebut.

Teknik pengambilan sampel pada penelitian ini menggunakan Non Probability Sampling yaitu teknik pengambilan sampel yang tidak memberi peluang atau kesempatan yang sama untuk dipilih menjadi sampel (Sugiyono, 2014). Untuk menentukan siapa yang akan dijadikan sampel menggunakan Accindental Sampling yaitu teknik pengumpulan sampel berdasarkan kebetulan yaitu siapa saja secara kebetulan bertemu dengan peneliti dapat digunakan sebagai sampel (Sugiyono). Dikarenakan jumlah populasinya tidak diketahui secara pasti maka untuk menentukan besarnya sampel digunakan rumus unknown populations yang dikemukakan oleh (Sarwono, 2013) sebagai berikut:

$\mathbf{n}_{0}=\frac{z^{2} p q}{e^{2}}$

\section{Keterangan :}

$\mathrm{n}_{0}=$ besarnya sampel

$\mathrm{Z}^{2}=$ Abscissa kurva normal yang memotong area sisi (tails), atau 1 tingkat kepercayaan sebesar 95\% atau 1.96

$\mathrm{e}=$ tingkat kepercayaan yang diinginkan $10 \%$

$\mathrm{p}=$ proporsi yang diestimasi suatu atribut yang dalam populasi yaitu 0,5

$\mathrm{q}=1-\mathrm{p}$

Dengan menggunakan rumus diatas, maka diperoleh perhitungan sebagai berikut:

$\mathbf{n}_{0}=\frac{(1,96)^{2}(0,5)(0,5]}{(0,1)^{2}}$

$\mathrm{n}_{0}=96,04=96$ responden

Dari hasil perhitungan tersebut maka diketahui besar sampel yang diperlukan adalah 96 responden.

\section{Metode Pengumpulan Data}

Dalam rangka pengumpulan data, penulis melakukan penelitian langsung, yaitu:

1. Penelitian Lapangan

a. Observasi merupakan proses untuk memperoleh data dari tangan pertama dengan mengamati orang dan tempat pada saat dilakukan penelitian (Sugiyono, 2014). Observasi dalam penelitian ini dilakukan terhadap mahasiswa Fakultas Ekonomi yang memilih tinggal di Langsa dengan menyewa kamar kost.

b. Wawancara merupakan teknik pengumpulan data dimana pewawancara (peneliti atau yang diberi tugas pengumpulan data) dalam mengumpulkan data mengajukan suatu pertanyaan kepada yang diwawancarai (Sugiyono, 2014). Wawancara dalam penelitian ini dilakukan terhadap mahasiswa Fakultas Ekonomi yang memilih tinggal di Langsa dengan menyewa kamar kost. 
c. Kuesioner merupakan instrumen untuk pengumpulan data, dimana partisipan atau responden mengisi pertanyaan atau pernyataan yang diberikan oleh peneliti (Sugiyono, 2014:230). Kuesioner diadopsi dari Septiana Indah dan Hafifah Rasti. Skala pengukuran yang digunakan yaitu skala Likert dengan alternatif jawaban sebagai berikut:

Sangat Setuju (SS) diberi skor 5

Setuju (S) diberi skor 4

Kurang Setuju (KS) diberi skor 3

Tidak Setuju (TS) diberi skor 2

Sangat Tidak Setuju (STS) diberi skor 1

2. Studi kepustakaan

Yaitu teknik pengumpulan data dengan menelusuri bacaan-bacaan dalam perpustakaan dalam rangka mencari keterangan-keterangan tentang buku serta bahan bacaan apa yang ada pada suatu perpustakaan.

\section{Metode Analisis Data}

Dalam penelitian ini, menganalisis pengaruh lokasi, harga, dan fasilitas terhadap keputusan sewa kamar kost menggunakan persamaan regresi linier berganda dikemukakan oleh Setiawan (2013):

$$
\mathrm{Y}=\mathrm{a}+\mathrm{b}_{1} \mathrm{X}_{1+} \mathrm{b}_{2} \mathrm{X}_{2+\ldots . .} \mathrm{b}_{\mathrm{k}} \mathrm{X}_{\mathrm{k}+\mathrm{e}}
$$

Keterangan :

$\mathrm{Y} \quad$ = Dependen Variabel

a $\quad$ Konstanta

$\mathrm{X}_{1} \mathrm{X}_{2} \mathrm{X}_{\mathrm{k}}=$ Independen variabel

$\mathrm{b}_{1} \mathrm{~b}_{2} \mathrm{~b}_{\mathrm{k}} \quad=$ Koefisien regresi

e $\quad$ error

Persamaan regresi linier berganda diatas dimodifikasi sebagai berikut:

$$
\mathrm{Y}=\mathrm{a}+\mathrm{b}_{1} \mathrm{X}_{1+} \mathrm{b}_{2} \mathrm{X}_{2+} \mathrm{b}_{3} \mathrm{X}_{3+} \mathrm{e}
$$

Keterangan:

$\begin{array}{ll}\mathrm{Y} & =\text { Keputusan Pembelian } \\ \mathrm{a} & =\text { Konstanta } \\ \mathrm{X}_{1} & =\text { Lokasi } \\ \mathrm{X}_{2} & =\text { Harga } \\ \mathrm{X}_{3} & =\text { Fasilitas } \\ \mathrm{b}_{1}, \mathrm{~b}_{2}, \mathrm{~b}_{3} & =\text { Koefisien regresi } \\ \mathrm{e} & =\text { error }\end{array}$


Pengujian hipotesis dalam penelitian ini adalah sebagai berikut:

1. Uji t (uji parsial)

Pengujian parsial digunakan untuk membuktikan apakah terdapat pengaruh antara lokasi $\left(\mathrm{X}_{1}\right)$, harga $\left(\mathrm{X}_{2}\right)$, dan fasilitas $\left(\mathrm{X}_{3}\right)$ terhadap keputusan sewa $(\mathrm{Y})$ :

2. Uji F (Uji simultan)

Pengujian simultan (Uji F) digunakan untuk menguji pengaruh secara bersama-sama terdapat pengaruh antara lokasi $\left(\mathrm{X}_{1}\right)$, harga $\left(\mathrm{X}_{2}\right)$, dan fasilitas $\left(\mathrm{X}_{3}\right)$ terhadap keputusan sewa $(\mathrm{Y})$.

3. Koefisien Determinasi $\left(\mathrm{R}^{2}\right)$

Koefisien determinasi $\left(\mathrm{R}^{2}\right)$ digunakan untuk menjelaskan proporsi variabel independen (lokasi, harga dan fasilitas) yang mampu menjelaskan variasi variabel dependennya (keputusan sewa). Menurut Santoso dalam buku (Priyatno, 2008), Adjusted $R$ Square adalah $R$ Square yang telah disesuaikan, nilai ini selalu lebih kecil dari $R$ Square dari angka ini bisa memiliki harga negatif, bahwa untuk regresi lebih dari dua variabel maka digunakan Adjusted $R$ Square sebagai koefisien determinasi.

\section{HASIL DAN PEMBAHASAN}

\section{Analisis Regresi}

Dalam mengetahui pengaruh variabel bebas (lokasi, harga dan fasilitas) terhadap variabel terikat (keputusan sewa) digunakan analisis regresi linier berganda yang diolah melalui program SPSS, sebagaimana ditunjukkan pada tabel berikut.

Tabel 1. Hasil Analsis Statistik

\begin{tabular}{lccc}
\hline \multicolumn{1}{c}{ Variabel } & B & T & Sig T \\
\hline Konstanta & 2,597 & 7,728 & 0,000 \\
Lokasi & 0,184 & 2,029 & 0,045 \\
Harga & 0,184 & 1,946 & 0,055 \\
Fasilitas & 0,004 & 0,782 & 0,436 \\
\hline Adjusted R Square & 0,170 & & \\
F & 7,486 & & \\
Sig. F & 0,000 & & \\
\hline
\end{tabular}

Sumber: Data Primer, diolah (2019)

Dari hasil tersebut dapat ditulis persamaan regresi sebagai berikut:

$$
Y=2,597+0,184 X_{1}+0,184 X_{2}+0,044 X_{3}
$$

Persamaan regresi berganda tersebut dapat dijelaskan sebagai berikut:

1. Konstanta sebesar 2,597 menunjukkan nilai keputusan sewa apabila lokasi, harga dan fasilitas bernilai tetap.

2. Variabel lokasi menunjukkan pengaruh yang positif dengan keputusan sewa sebesar 0,184 . Dengan kata lain, apabila lokasi naik satu satuan maka keputusan sewa akan meningkat sebesar 0,184 satuan dengan asumsi variabel harga dan fasilitas tetap. 
3. Variabel harga menunjukkan pengaruh yang positif dengan keputusan sewa sebesar 0,184. Dengan kata lain, apabila harga naik satu satuan maka keputusan sewa akan meningkat sebesar 0,184 satuan dengan asumsi variabel lokasi dan fasilitas tetap.

4. Variabel fasilitas menunjukkan pengaruh yang positif dengan keputusan sewa sebesar 0,044. Dengan kata lain, apabila fasilitas naik satu satuan maka keputusan sewa akan meningkat sebesar 0,044 satuan dengan asumsi variabel lokasi dan harga tetap.

\section{Hasil Uji Koefisien Determinasi}

Berdasarkan Tabel 1 terlihat nilai Adjusted R square sebesar 0,170. Hal ini berarti variabel lokasi, harga dan fasilitas mempengaruhi keputusan sewa kamar kost pada Mahasiswa Fakultas Ekonomi Universitas Samudra sebesar 17,0\%, sementara sisanya 83,0\% dipengaruhi oleh variabel lain yang tidak diteliti dalam penelitian ini seperti kelompok acuan, keamanan, dan lain sebagainya.

\section{Pembuktian Hipotesis}

\section{Uji t (Uji signifikan parsial)}

Dari Tabel 1 dapat dijelaskan bahwa:

a. Hasil nilai signifikan sebesar 0,045 $<0,05$ maka hipotesis diterima, yang berarti bahwa lokasi berpengaruh signifikan terhadap keputusan sewa. Hasil ini sama dengan penelitian yang dilakukan oleh Septiana Indah Tyas dan berbeda/bertentangan dengan penelitian yang dilakukan oleh Hafifah Rasti yang menyatakan bahwa variabel lokasi tidak memberikan pengaruh terhadap keputusan sewa kamar kost.

b. Hasil nilai signifikan 0,055 >0,05 maka hipotesis ditolak, yang berarti bahwa harga berpengaruh tidak signifikan terhadap keputusan sewa. Hal ini dikarenakan harga tidak memberikan pengaruh terhadap mahasiswa dalam keputusan untuk menyewa kamar kost. Hal ini berbeda/bertentangan dengan penelitian yang dilakukan oleh Hafifah Rasti yang menyatakan bahwa variabel harga berpengaruh signifikan terhadap keputusan dalam memilih rumah kost, hal ini dikarenakan sebagian besar mahasiswa memberi tanggapan setuju pada pertanyaan "pembayaran biaya kost dapat dilakukan secara tahunan".

c. Hasil nilai signifikan 0,436 > 0,05 maka hipotesis ditolak, yang berarti bahwa fasilitas berpengaruh tidak signifikan terhadap keputusan sewa. Hal ini dikarenakan fasilitas tidak memberikan pengaruh terhadap mahasiswa dalam keputusan untuk menyewa kamar kost. Hal ini berbeda/bertentangan dengan penelitian yang dilakukan oleh Hafifah Rasti yang menyatakan bahwa fasilitas berpengaruh signifikan terhadap keputusan sewa rumah kost, hal ini dikarenakan dari hasil tanggapan responden, pemilik kost telah menyediakan fasilitas umum seperti dapur, tempat parkir, ruang tamu, tempat mencuci, atau kamar mandi. 


\section{Uji F (Uji Signifikan Simultan)}

Dari Tabel 1 diatas dapat diketahui nilai F sig. Sebesar 0,000. Oleh karena nilai F sig. 0,000< 0,05 maka dapat dinyatakan bahwa lokasi, harga dan fasilitas secara simultan berpengaruh signifikan terhadap keputusan sewa. Dengan demikian maka hipotesis dalam penelitian ini diterima. Hasil ini sama dengan penelitian yang dilakukan oleh Ghanimata dan Kamal yang menyatakan berdasarkan hasil analisis regresi berganda dapat dilihat bahwa semua variabel harga, kualitas produk, dan lokasi berpengaruh positif terhadap keputusan pembelian.

\section{KESIMPULAN DAN SARAN}

\section{Kesimpulan}

Setelah dilakukan pengujian, hasil penelitian dan pembahasan maka dapat disimpulkan yaitu: hasil persamaan regresi linier berganda diketahui bahwa lokasi berpengaruh positif terhadap keputusan sewa kamar kost, harga berpengaruh positif terhadap keputusan sewa kamar kost dan fasilitas berpengaruh positif terhadap keputusan sewa kamar kost. Dari analisis koefisien determinasi dapat dijelaskan bahwa lokasi, harga dan fasilitas mempengaruhi keputusan sewa kamar kost pada mahasiswa Fakultas Ekonomi Universitas Samudra. Dari uji t diketahui bahwa lokasi berpengaruh signifikan terhadap keputusan sewa kamar kost pada mahasiswa Fakultas Ekonomi Universitas Samudra. Harga berpengaruh tidak signifikan terhadap keputusan sewa kamar kost pada mahasiswa Fakultas Ekonomi Universitas Samudra. Fasilitas berpengaruh tidak signifikan terhadap keputusan sewa kamar kost pada mahasiswa Fakultas Ekonomi Universitas Samudra. Dari Uji F diketahui bahwa lokasi, harga dan fasilitas secara simultan berpengaruh signifikan terhadap keputusan sewa kamar kost pada mahasiswa Fakultas Ekonomi Universitas Samudra.

\section{Saran}

Saran dalam penelitian ini yaitu: berdasarkan variabel lokasi, pemilik kost sebaiknya membangun tempat kost disekitar kampus Fakultas Ekonomi agar mahasiswa Fakultas Ekonomi tidak perlu mengeluarkan biaya transportasi. Berdasarkan variabel fasilitas, sebaiknya pemilik kost menyediakan berbagai fasilitas yang dapat mempermudah mahasiswa dalam melakukan segala kegiatan maupun aktivitas sehari-hari, misalnya: kamar mandi, tempat parkir, dan meja belajar. Untuk peneliti selanjutnya, sebaiknya dilakukan dengan meneliti variabel-variabel lain yang berkaitan dengan rumah kost dan memperluas responden tidak hanya pada mahasiswa Fakultas Ekonomi saja, tetapi dapat memperluas sampel pada wilayah yang lain sehingga daya generalisasi hasil penelitian dapat diperbesar

\section{REFERENSI}

Ghanimata, Fifyanita dan Mustafa Kamal. 2012. Analisis Pengaruh Harga, Kualitas Produk, dan Lokasi terhadap Keputusan Pembelian. Diponegoro Journal of Management. Vol 13. No 2. Hal: 1-10 
Hajar, Susilawati dan Nilakusmawati. 2012. Faktor-Faktor yang Mempengaruhi Keputusan Mahasiswa dalam Memilih Rumah Kost. e-Jurnal Matematika. Vol 1. No 1. Hal: 23-31.

Hasan, Ali. 2013. Marketing dan Kasus-Kasus Pilihan. Yogyakarta: CAPS.

Heizer, Jay dan Render Barry. 2015. Manajemen Operasi: Manajemen Keberlangsungan dan Rantai Pasokan, Edisi 11. Jakarta: Salemba Empat.

Kotler, Philip. 2007. Manajemen Pemasaran. Jakarta: PT Indeks.

Kotler, Philip dan Garry Armstrong. 2008. Prinsip-Prinsip Pemasaran. Jilid 1. Edisi 12. Jakarta: Erlangga.

Kotler dan Keller. 2009. Manajemen Pemasaran. Jilid 1. Edisi 13. Jakarta: Erlangga. . 2009. Manajemen Pemasaran Jasa. Jakarta: Salemba Empat.

Kotler, dan Keller. 2012. Manajemen Pemasaran. Edisi 12. Jakarta: Erlangga

Kurniawan, Andre. 2015. Analisis Pengaruh Lokasi dan Fasilitas terhadap Keputusan Mahasiswa Memilih Tempat Indekos dengan Harga Sewa Indekos Sebagai Variabel Moderasi. Jurnal Ekonomi dan Kewirausahaan. Vol 15. No 2. Hal: 236-244.

Laksana, Fajar. 2008. Manajemen Pemasaran. Yogyakarta: Graha Ilmu.

Lupiyoadi, Rambat dan A. Hamdani. 2011. Manajemen Pemasaran Jasa. Edisi Dua. Jakarta: Salemba Empat.

Resmi, Ni Nyoman dan Mekarsari, Ni Ketut Adi. 2011. Faktor-Faktor yang Mempengaruhi Perilaku Anak Kos dalam Pemilihan Rumah Pemondokan di Kota Singaraja. Jurnal Sains dan Teknologi. Vol 11. No 1. Hal: 112-118.

Priyatno, Dewi. 2008. Mandiri Belajar SPSS - Bagi Mahasiswa dan Umum. Yogyakarta: MediaKom.

Rasti, Hafifah. 2015. Pengaruh Lingkungan, Harga, Fasilitas, dan Kelompok Referensi terhadap Keputusan Konsumen dalam Memilih Jasa Rumah Kost di Kawasan Limau Manis dan Jati. Skripsi. Universitas Andalas, Padang.

Sarwono, Jonathan. 2013. Strategi Melakukan Riset. Yogyakarta: Andi.

Septiana, Indah Tyas. 2009. Pengaruh Promosi, Lokasi, Fasilitas, Harga dan Kelompok Acuan Terhadap Pemilihan Tempat Kos. Skripsi. Universitas Sanata Dharma, Yogyakarta.

Setiawan, Budi. 2013. Menganalisa Statistik Bisnis dan Ekonomi dengan SPSS 21. Yogyakarta: Andi.

Siahaan, Stephani. 2018. Analisis Faktor yang Mempengaruhi Keputusan Mahasiswa dalam Pemilihan Tempat Kost di Wilayah Universitas Sumatera Utara. Skripsi. Universitas Sumatera Utara, Medan.

Sugiyono. 2014. Metode Penelitian Manajemen. Bandung: Alfabeta.

Sumarwan, Ujang. 2012. Riset Pemasaran dan Konsumen. Bogor: IPB Press.

Sunyoto, Danang. 2014. Dasar-Dasar Manajemen Pemasaran (Konsep, Strategi, dan Kasus). Cetakan 1. Yogyakarta: CAPS.

Tjiptono, Fandy. 2015. Strategi Pemasaran. Edisi 4. Yogyakarta: Andi. 